\title{
Gender Discrimination: Implications for Pakistan Security
}

\author{
${ }^{1}$ Hamid Iqbal, ${ }^{2}$ Saima Afzal, ${ }^{3}$ Mavara Inayat \\ ${ }^{1,3}$ Department of International Relations, Quaid-i-Azam, University Islamabad, Pakistan \\ ${ }^{2}$ Department of Peace and conflict studies, National Defence University Islamabad, Pakistan
}

\begin{abstract}
Gender discrimination is a non-tradition security threat to Pakistan and it has implications for Pakistan security. Pakistani women are more than half of the total population, but women are treated inhumanly within their homes by their husbands or dominant males through different ways like Domestic Violence, Sawara, Vani, Karo Kari, Honour Killing, Acid Throwing, Forced Marriages etc. Gender discrimination is also deeply rooted in Pakistani society in education and employment sectors. The security of a state like Pakistan is connected with the security of whole population and a country cannot be considered secure until its whole population feel secure. For the progress and prosperity of a country there is needed to eliminate the discriminatory attitude of the society towards the women. There are multiple ways to improve gender balance in the country which will reduce gender discrimination.
\end{abstract}

Key Words: Gender Discrimination, Education Sector, Employment Sector, Gender and Human Security.

\section{Introduction}

This study discusses gender discrimination as 'non-traditional security' threat to the country. It argues that women are more than half of the population and the security of women is associated with state security. This is so because no country can be secure until its whole population feels secure. Pakistan needs to empower its women for the progress and prosperity of a country. Balance has been maintained by the nature in all things of the world in order to decorate it with exquisiteness, and it produced a feature that sustains balance in each and every thing. These harmonizing features vary in the ratio that provides to support their accompaniment. In this perspective men and women are well thought-out as the supporting complement for each other, but the main clash in this logic maintain is the term 'gender discrimination'.

The term discrimination refers to unequal behavior able to improve or limit a situation. Normally it is harmful because groups are treated unfairly based on prejudice(s). Discrimination is a 'rejection process' of the other, emphasizing on gender, race, sex, age (children, adolescents, elder), social and marital status, class and caste belonging, political and institutional discrimination (governments, aid agency, spenders), migrant or refugee status, religion, incapacity, handicap (disability, illness, HIV-status) etc. While Gender discrimination refers to different treatment based on sex, including different connotations of values that change with cultural context. It is the most common and longstanding discrimination, and it is triggered by other discriminative behaviors. Gender discrimination is loftily based on gender stereotype of a fastidious culture, i.e. that considers males physically powerful and consider females as psychologically sensitive or weak. Due to this term 'gender' is often clashes with the term 'sex'. Both terms are used as interchangeably in a common perspective, but there has been a scientific dissimilarity among both. 'Sex' is genetic differentiation of persons; classify them as men and women, this distinction of persons is similar in all the cultures of world, whereas 'gender' is a societal delineation of persons which classify them as 'male' and 'female'. This distinction verifies the function of persons in a fastidious culture. The responsibility of persons in diverse culture is dissimilar and thus the responsibility of gender is changeable in accordance with the existing societal setup.

Gender discrimination defines the practice of granting or denying rights or privileges to a person(s) based on their gender. In some societies, this practice is ancient and satisfactory to both genders. Few religious groups hold gender discrimination as part of their dogma. However, in most developed countries, it is either unlawful or generally considered unsuitable.

The gender discrimination approach can generally be found in the heredity of certain section of society. Much of the prejudice is recognized to stories such as a woman being made from a man's rib and social community practices such as dowries paid to fathers by prospective husbands to purchase their daughters to be wives. Innumerable literature orientation is made to females being the fairer, weaker sex, and males being the strong, unconquerable hunters of the world. The collective authority of these societal and religious values left little room for impartial thoughts for centuries.

Gender inequalities have existed form a long time, but currently, it has greatly threatened the security of the state. Everyday forms of violence that occur within our homes include gender discrimination in intrahousehold food distribution, 'lack of access to education and health', 'early and forced marriages', 'denial of inheritance right', 'restriction on women's mobility', 'verbal abuse', 'physical and sexual violence against 
women by male family members' etc. Mistreatment and violence also take place in the name of culture; such as local customs of Watta-Satta, Swara, Vani, and Karo-Kari etc have also become widespread and acceptable. The study is divided in five sections. The first section is about the gender discrimination in Pakistan. The second and third section elaborates respectively gender discrimination in education and employment sector. The fourth section discusses gender and human security whereas the final section elaborates women empowerment during military and democratic regimes.

\subsection{Gender Discrimination In Pakistan}

This section discusses the gender discrimination in Pakistan. It especially highlights domestic violence, honor killings, Swara and Vani, acid throwing and forced marriages. Pakistan is a developing country which is confronted with a numerous problems; like poverty, illiteracy, prejudice, joblessness and human rights violence and gender chauvinism. However, the most critical and emerging issue are gender inequality and disparity in Pakistan. It survives approximately in all segment of society.

Women in Pakistan constitute more than half of the total population, but they are relegated to a secondary role. Global experiences have repeatedly established that gender-based violence is persistent across in Pakistan, and has its roots in a patriarchal social structure in which women are submissive to men, and are viewed as property. Their physical hardship and their contribution to production are not acknowledged. Rather the realities of women's lives are neglected or ignored by the society's attitudes and treatment towards them. The discriminatory attitude towards women as inferior is observed even before their birth. Even a mother greets a girl child with guilt or despair. As a person, a woman is denied her own identity. A woman suffers from a neglect health, education and gender biased feeding. She is considered a commodity possessed by her father before marriage, then by her husband after marriage. She has no right to take independent decisions that influence her life tremendously. Someone else takes decisions on her behalf regarding education, marriage, or giving birth to a child, not by herself. It shows the structure that is reproducing and promoting an unequal relationship between the two genders.

The gender discriminatory structure has deep roots. Women are often convinced that the work they do at home is their duty and that they do not need and should not expect any reward for it. While, the work is done by men is considered more valuable in the sense of social and economic value. Similarly, women do not participate in decision making. To break this structure there is dire need to empower the women. In Pakistan the status of women is much better in the urban areas when compared to the rural areas.

The past decade has witnessed escalating levels of violence against women, children and other weak groups in Afghanistan, Pakistan and Iraq Gender discrimination is wide spread in Pakistan and leads to women's insecurities in all sphere and all stages, as indicated by official statistics on education, employment, nutrition health, and political participation. There are structural inequalities and discrimination against women. John Galtung, the Norwegian peace scholar described the 'Structural Violence' "the endemic violence which exists in the disparity of a community's structure"; where gross power inequity within a system harm people's life chance as obvious in universal discrimination- linguistic, caste, sexual, racial, economic ,religious, etc.

The society structures of gender create male authority and power over women, and produce a gender based aggression in society. Women's security cannot be separated from the broad issue of patriarchy; which translates into the women's insecurities in all the sphere of life making them structurally disempowered, excluded and subjugated due to unequal relationships. Structural inequalities and issues of poverty, development and globalization have strong linkages with women's security because they all play a strong role in violence against women, be it economic, political, cultural or physical.

Although violence against women is a universal phenomenon, but the extent and form of violence differs from one society to another society. Considering the enormous dimension of issues related to women's security in Pakistan, the followings are the dimensions of gender discrimination.

No country or society is free of the domestic violence. Millions of women suffer from domestic violence all around the world. Even the developing countries are not free from this evil. In Pakistan, domestic violence is considered a private matter, as it occurs in the family and therefore not an appropriate focus for assessment, intervention or policy changes. In Pakistan society women have to face violence and prejudice every day in every field due the religious and cultural norms. According to an estimate, around 70 to $90 \%$ of Pakistani women suffered domestic violence. Domestic violence in the country includes mental, psychological, sexual, physical and emotional abuse. Some general kinds comprise of honor killing, spousal abuse including marital rape, acid attacks and being burned by family members. Spousal mistreatment is seldom considered a sin socially unless it takes a severe type of murder or attempted murder which could vary from driving a woman to suicide to injuring an accident (normally the bursting of a kitchen oven).

Domestic violence is considered as a private matter which is not of any concern to the courts. Women are usually ignorant of the fact that violence is a crime. The aggressors are the close relatives of the women, few women come forwards to report the abuse to the police. Usually, they are threatened to be a silent. Social taboos and the lack of family support for shelter leaves women with no alternative except to bear their lot. According to 
a survey which was conducted on 1000 women in Punjab, the 35\% of the women admitted in the hospitals reported being beaten up by their husbands. The survey also revealed that at least two women were burned every day in domestic violence occurrence and around about 70 to $90 \%$ of women experienced spousal abuse.Honor killing is another form of domestic violence against women in Pakistan. The practice of Karo Kari is known to occur in many parts of the country.

Honour killing is one of the most horrible forms of brutality against women. It is a severe type of direct physical violence, which is noticeable by immense misery. In contemporary scenario, Pakistan has been criticized because of the dramatic increase in the occurrence of honor killings in the state. It is necessary to know about definitions and genuine reasons behind the brutal murder of females in the name of honour. Honour killings can also be explained as extra-judicial penalty of a female relative for implicit sexual and marriage offences. These offences, which are considered as a transgression or abuse, include sexual faithlessness, marrying without the will of parents or having a relationship that the family considers to be wrong and rebelling against the tribal and social matrimonial customs. These acts of killing women are justified on the basis that the offence has brought disgrace and dishonor to family or tribe.

In Pakistan honor killing is known as Karo Kari in Sindh, Siya Kari in Balochistan, Kala Kali in Punjab and Tora-Tora in KPK. Karo is the name for the male offender and Kari is used for female offender. Both means black. Siya, Kala and Tora also mean black denoting the dark color of crime being punished.

Karo Kari traditionally means the right of community or near relatives, husband, father, or brother to kill the female relative and her paramour for an illicit sexual relationship outside marriage. Presently the tradition is misused and murders are justified in cases merely based on suspicious or where the male or female marry or seek a divorce without the consent of the family. The tradition is also misused in murders for ulterior motives.Sadly, by and large, honour killing has become an honourable institution in Pakistan. Those who commit the murder for vindicating their honour are applauded by their peers. In police custody and in the jails such persons are given special protocol for killing on the name of honour or ghairat.

Honour killing is pre-Islamic and not supported by Islam. The custom of honour killing is centuries old. It has survived with the patriarchal family system. The tribal system is prevailed in Pakistan especially in northern and remote areas. In some tribal areas the tribal laws coexist with the state laws. According to state laws honour killing is considered as a crime, though a lenient view is taken by courts. Under the tribal laws it is not considered as crime and it is legitimate to kill to avenge the violation of honour.

According to press reports, the incident of honour killing are high after 9/11 in Sindh especially in upper Sindh, as in those areas Pathans are living as well as settlers from Afghanistan, Balochistan and Southern Iran. These groups have not changed their customs, which is the reason why women are targeted for revenge. These crimes against women are part of feudal society. There are three reasons for honour killing revenge, property and loan. In the matter of revenge a women of the family is killed and blamed on enemy that she had illicit relationship and that murder is an honour killings. Women are killed due to the distribution of property for inheritance. Swara and vani traditions are also violation of women rights in Pakistan and threat to women security. Swara is centuries old custom practiced in Pakistan and Afghanistan, especially in Pakhtun tribal societies. The genesis of this custom is obscure but different sources confirm that it developed as gesture of goodwill to end blood feud. The word Swara mean in Persian riding on horse or any other animal used for traveling. Today in tradition terminology Swara refers to a girl given over to aggrieved family as compensation for blood.

Swara practiced today is extremely derogatory to women as it violates their human rights and makes them a mere commodity by giving them over to victim party for reconciliation in case of rivalry, murder or abduction. When a case of murder comes up before the Jirga for a solution and Jirga announced the punishment. In a case of murder the punishment is either revenge; blood for blood or money or Swara. The nearest virgin girl daughter, sister, niece etc of the offender is given to the aggrieved family. Since it is forced marriage between enemies so there is no wedding ceremony. The girl suffers from this connection because she is merely considered as a punishment of enemy.

A similar custom of marrying young girls for the settlement of disputes also takes place in the rural parts of central Punjab Province of Pakistan where this practice is known as Vani. There are different sources which confirm degrading practices of offering and accepting women on order of Panchayat in many parts of rural Punjab and the tribal areas in Khyber PukhtoonKhwa KPK but since most cases these are unreported, there is no reliable statistics on how many girls are given in vani or Swara every year in Pakistan.

Acid throwing is a horrible and alarming form of violence against women. It is the violation of human rights of women. In this brutal form of violence the perpetrators throw the acid on the faces of victim which not only disfigure their face but also burn tissues of their body. These incidents cause the blindness and permanent scars on the body. Mostly women are victim of such terrible attacks. According to an estimate there are four hundred females in Pakistan who annually become a victim of this heinous act of violence by their husbands and in-laws. 
There are many reports which indicate the reasons behind these brutal acts. Mostly the acid towing incidents occur due to the refusal of sexual advances, proposal for marriages and demand for dowry. Property dispute is also a cause of such incidents, acid throwing has been used as a strategy for taking revenge of above mention causes. There are very few cases of acid throwing which are registered in Pakistan, because mostly influential people of society are supporting the perpetrator. Belonging to the poor and marginalized fringes of the society, most acid survivor can hardly affords the expenses of treatment.

Depression and anxiety become a part of such victims because due to scars on their faces they feel ashamed and embarrassment. According to a survey from May 2004 to May 2006 in 14 Districts of Punjab 65 were reported, in 2008 there were 24 and in 2009 there were 27 cases reported.

Forced marriages are also violation of women rights in Pakistan. Pakistan has a strong patriarchal system in the society. Marriages within the clan and family are common in Pakistani society and it is considered as a strong bondage between the two families. According to an estimate 40 to 60 percent marriage occur between the close biological relatives. Parents decide the fate of their daughters and female have no right to choice a partner on their own choices.

In the feudal families of Pakistan the daughters are married to the paternal cousin to prevent the distribution of lands outside the family by inheritance. At times, a girl is married to a younger cousin to her which is a complete mismatch. In such marriages the husband later marries a woman of her own choice and with her and children, ignoring her cousin wife. She is often left alone childless in the village. Even Pakistan's former Prime Minister Zulfiqar Ali Bhutto, was married with his cousin at his early age who was elder than him. She remained childless.

Where there is no possibility of marriage of girl with cousin or within the family the girl is guided into the custom of Haq Bakhshi, marriage with the Quran, denying her all the advantages of matrimony. She is considered as a pious female who cut off from the worldly affairs. This practice is prevailing in the province of Sindh, which is the great discrimination of gender.

\subsection{Gender Discrimination in Education Sector}

This section discusses that there is gender inequality in education sector also in Pakistan. Gender disparities also exist in educational achievement between rural and urban areas among the provinces in Pakistan. As above described that Pakistan is a patriarchal society, where women suffer all types of prejudice, resultant in low social, economic and political status in the society. United Nation Development (UNDP) 1999 Report clearly shows that the gender gap is growing in all social segment of Pakistan. Pakistan ranks 120 in 146 countries in terms of gender- related development index, and in terms of gender empowerment measurement ranking, it ranks 92 in 94 countries. Gender inequality in education can be measured by looking the gross and net enrollment rates and completion and drop rates. Cultural boundaries discourage parents from sending their daughters to co-education schools. There have been circumstances when the girls are registered in boys' institutions up to Matric level, representing those institutions of girls falling short. Likewise, poor physical environment or lack of fundamental services in educational institutions also discourages parents from sending their girls to schools for education.

National Educational Policy of Pakistan 2007 indicates that the educational status of women in Pakistan is awful and low, in fact, amongst the lowest in the world. The problem starts at the primary level, where low participation of women and high dropouts at that stage prevents females from reaching higher education. The Ministry of Women Development 2007 report indicates that only $19 \%$ of females have attained education up to Matric, $8 \%$ up to Intermediate, $5 \%$ a Bachelor's degree and $1.4 \%$ achieved a Master's degree. $60 \%$ of the female adult population is illiterate. Of the 3.3 million out of school children, 2.503 million are girls. $73.6 \%$ of primary age girls attend school, compared with $92.1 \%$ of boys. Moreover, majority of rural girls drop out of primary schools.

In rural areas, there are limited opportunities for women while women belong to the upper and middle classes have greater access to education and employment opportunities. Educated and professional women in urban areas of the society enjoy much better status and rights than unqualified and illiterate women in rural and remote areas of Pakistan. Women in tribal areas of Balochistan, KPK and remote areas of southern Punjab and Interior Sindh live in more horrible social circumstances than women in other parts of the country. In urban areas girls actively join the professional and technical education. But after getting technical and professional qualification they are not permitted to use their talent for the development of country economy; that's why we don't find as many females in offices as compare to males. This is the main drawback as it leads a nation towards economic disadvantage, as the half populations of females do not participate in economic activities. Mostly girls become doctors, but they do not practice due to social issues. 


\subsection{Gender Discrimination in Employment Sector}

The women in Pakistan have seen discrimination in employment more than males. There are many factors of female employment discrimination like low literacy rate, marriage, and child bearing and the environment. Many female are not allowed to do job with a male in Pakistani society, because it is considered against the honour of family. It is a male dominated society and mostly family males do not want that their daughters and sisters to work on an equal basis with them. To provide the safe environment free of harassment and implementation of "Protection against harassment of women at workplace" bill will take a time to change the mind set of society.

In the past two decades, in Pakistan, there has been little change in the organization of work in the employment sector. Now women are entering into professional employment which was previously considered a male domain. Women work is getting recognition as being essential for development of the economy and for improving their status. However by keeping the same idea in mind most women are still discriminated against the employment sector. Employment laws in the formal sectors do not discriminate against men and women, there the same rules apply in the promotion, and there is also no discrimination of male and female pay scale in same the grade. However, a recent study on women employment in formal sectors show that despite the equal legislation women are still discriminated when it comes to the matter of promotion.

In the employment sectors there are fewer females in decision making and there are very few females as compare to male in the higher posts. The group of 2005 federal Government district management group study clearly shows how female are discriminated and very few females reached the highest posts.

District Management Group

\begin{tabular}{|l|l|l|l|}
\hline Basic Pay Scale (BPS) for Government Employees in Pakistan & Male & Female & Total \\
\hline 22 & 10 & 0 & 10 \\
\hline 21 & 47 & 03 & 50 \\
\hline 20 & 231 & 10 & 241 \\
\hline 19 & 266 & 14 & 280 \\
\hline 18 & 88 & 6 & 94 \\
\hline 17 & 113 & 8 & 121 \\
\hline
\end{tabular}

Source: Posting List Establishment Division, Government of Pakistan 2005.

These are the positions where most planning and development matters are decided but women are not fairly represented and given an opportunity to participate in decision making. Due to this discrimination women needs are not address in policy and planning matters. Positive change in women empowerment can only be achieved if women are able to participate in open, transparent, and accountable decision making process of law and policymaking institutions.

Medicine and education are two departments where women are employed in large numbers. In all girls schools and colleges only females are appointed as heads of institution, where as in co-education institution heads, chancellors and vice chancellors are male. There are female teachers in such institutions but no female heads of co-education institutions is found till yet. The number of women on top level institutions indicates the scarcity of data on women participation in different employment sectors. In the informal sectors the women are employed in low cadre jobs in industrial units. Hardly any women reach the managerial level. There is also discrimination in the wages of male and female in informal sectors.

\subsection{Gender and Human Security}

Gender is a part of the security dynamic particularly through societal security and enunciation of identities. Gender identities expose poverty, violence, limited access to resources and restriction on freedom. Gender security need and find responses (positive security and negative) by the state, by communities and by individuals.

Human security was first come into light in the United Nation Development Programme's 1994 Human Development Report. Dr Muhboob-ul-Haq is the prominent pioneer of human development and security studies. He put the complex idea into simple words. He interpreted the security as

- Security of the people not only territory

- Security of the individual not only nations

- Security through must be in shape of development in areas not through arms

- Security of all the people in all places in homes, in their jobs, in their society, in their streets and in their surroundings.

The focal point of human security is on serious abandon of gender concerns under the traditional security model. Traditional security's focus on outside armed intimidation to the state shows that the threat within the country that women face has been ignored. The focal point of human security is the individual; and 
the aim of the human security model is to address the security concerns of both women and men equally. Women are often the worst victims of aggression and clashes: they form the majority of civilian deaths, the majority of refugees, and, are often the victims of cruel and humiliating practices, such as rape. Women's security is also threatened by unequal access to resources, services, and opportunities. Human security seeks to give power to women, through education, contribution, and access, as gender parity is seen as an essential prerequisite for peace, security, and a flourishing society.

Gender security is basically the extension of Human security. Both are interlinked with each other because in both there has been talked about the human as an individual. Human security is a comprehensive concept; the basic pillar revolves around both the individual and the state. A state is expected to provide both physical as well as economic security. Just as physical security implies safety both from internal sources of threats as well as from external aggression, human security implies that the citizens are being provided with an environment in which they maximize their potentials. Physical security has to deal with both internal as well as external sources of threats. However, human security covers freedom from want, discrimination, injustice, exploitation, food insecurities, and environmental degradations.

Human security simply emphasis, that the security agenda and the development agenda are the different sides of the same coin. Both sustainable human security and sustainable human development must be found on the protection of fundamental human rights and require a democratic society. What sets human security apart is its unifying, holistic character. This mean that the dimensions affecting people's security/ insecurity can be determined and the concept of security extended in economic, political, social, environmental, and cultural aspects.

\subsection{Women Empowerment During Military and Democratic Regime}

Women are the vital segment of any society. No nation can make progress without the participation of women in economic, social, and political sphere. In Pakistan different governments took different steps for women empowerment and gender discrimination in the society which is the following.

Zulfiqar Ali Bhutto's democratic regime (1970-77) is considered as a land mark in the history of women development in Pakistan. He was having a liberal attitude towards the women empowerment. First time in Pakistan all the government services were opened for the females including the district management group and foreign services of Pakistan. The promulgation of the 1973 Act further advanced the women's legal position; article 25 of the fundamental rights promised that all citizens are equivalent under the rule and prohibit the prejudice on the basis of sex. Articles 27 of 1973 constitution also prohibit the prejudice on the basis of gender, creed and class in the service. The constitutions also reserve the seat for women in the national assembly to contest in election. In 1975 Pakistan was also one of the supporting nation of the United Nation Convention on the Elimination of All Form of Discrimination against Women.

During the General Zia-ul-Haq (1977-1986) martial law regime, the Sixth Plan was based on inconsistency. His regime had taken many steps for the women empowerment, such as the establishment of the Women's Division in the Cabinet Secretariat, and the appointment of another commission on the status of women. For the first time in the Sixth Plan a chapter on women in development was included. In 1981, General Zia-ul-Haq designated the Majlis-e-Shoora (Federal Advisory Council) and appointed 20 women as members; however Majlis-e-Shoora had no power over the decision-making division. In 1985, in the National Assembly elections women's reserve quota was doubled by ( 20 percent).

However, Zia-ul-Haq started a policy of Islamization such as the set of Hudood Ordinances and the Qanun-e-Shahadat Order .He prohibited the women participation in games and encouraged purdah. He perched all essential human rights definite in the 1973 charter, with the right to be free of prejudice on the basis of sex. $\mathrm{He}$ also projected laws of Qisas (retaliation) and Diyat (blood money). The Zina Ordinance included zina-biljabr, if the woman who accuses a man of zina-bil-jabr (rape) cannot prove to the judicial system that she was raped, she faces adultery charges. In order for a rapist to receive "hadd", the maximum punishment provided for under the Quran, either the rapist must admit to the rape, or four virtuous and mature Muslim men must witness the "act of penetration" themselves and give evidence against the rapist. Under Qanun-e-Shahadat, a woman's witness was not considered uniformly to that of a man. Thus, if a woman does not have male witness but does have a female witness, this would not qualify as necessary proof. The rapist may be acquitted and the victim may face adultery charges. The threat of being prosecuted dejected victims to file complaint.

Benazir Bhutto was the first female Prime Minister of Pakistan In 1988, she was also first head of elected Muslim country. Though, during her two shortened tenure of rule (1988-90 and 1993-96), Benazir Bhutto did not recommend any legislation for the welfare of women. By virtue of the eighth constitutional amendment imposed by Zia-ul-Haq, these laws were protected both from ordinary legislative modification and from judicial review. In 1989, the Ministry of Women's Development (MWD) established women's studies centers at five universities in Islamabad, Karachi, Quetta, Peshawar, and Lahore. However, four of these centers could not function due to lack of economic and administrative support. Only the center at University of Karachi (funded by the Canadian International Development Agency) was able to run a Master of Arts program. 
In 1989, the First Women Bank Ltd (FWBL) was also established to address women's economic needs. It operates 38 branches across the country, managed and run by women. It finances small-scale credit schemes for underprivileged women. The Social Action Program begins in 1992/93 aimed at reducing gender inequality by improving women's access to social services.

In 1997, the Nawaz Sharif government formally ratified the Qisas and Diyat Ordinance, which introduced Shariah-based modification in Pakistan's criminal law. The law had earlier been reserved in force by appeal to the president's power to re-issue it every four months. Sharif then projected fifteenth modification to the charter that would completely restore the existing legal system with a complete Islamic one and would control the "constitution and any law or decision of any court". The suggestion was accepted in the National Assembly, due to the huge majority of Nawaz Party. However, it deferred in the Senate because it faced the opposition from human right activities, women's group an opposition parties. On 6 August 1998, Pakistan's first Women University, was inaugurated named after Fatima Jinnah the sister of Quaid-i-Azam.

On September 2, 2004, the MWD was made completely autonomous ministry, disconnected from the social Welfare and Education Ministry. On July 7, 2006 General Musharaff signed a law for the instant discharge on bail approximately 1300 women who suffered in jails on accuse other than terrorism and murder. His government improved women status in assemblies by providing more seats. As contrast with 1988 seats in the National Assembly were enlarged from 20 to 60. In provincial assemblies 128 seats were for women. It has brought out enlarge contribution of women for 1988 and 2008 elections.

In late 2006, the Pakistani parliament approved the Women's Protection Bill, and revoked the Hudood Ordinance. The $10 \%$ quota was increased for female in Central Superior Services which was approved by the cabinet. During same year in 2006, the cabinet passed the Protection of Women Act. In December 2006, for the first time, women cadets from the Military Academy Kukul assumed guard duty at the mausoleum of Muhammad Ali Jinnah.

On March 09, 2010, President of Pakistan signed the "The Protection against Harassment of Women at Workplace Act Bill 2010" which was collectively passed by the National Assembly on Jan 21, 2010, and by the Senate on Feb 26, 2010. The Act means to provide the safe working environment to females in all Government, Public/Private Sector organizations \& Educational Institutions are required to apply it, inside the 30 days of circulation. April 11, 2010. The punishment for the crime is up to three years in prison and a fine of up to Rs 500,000 . The objective of the bill is to create a safe working environment for women, free of harassment, violence and pressure.

The Prevention of Anti-Women Practices Bill 2011 was approved on 15 November 2011 by National Assembly of Pakistan after the much great efforts of the women movement led by Dr Donya Aziz (PML-Q). The Prevention of Anti-Women Practices Bill 2011 outlines strong punishments for social practices like Vani, Swara or Budla-i-sulh, wherein women are traded to settle personal, family or tribal disputes. For the first time, the bill proposes a minimum benchmark for penalizing those involved in "anti-women practices".

There are following major issue of the Prevention of Anti-Women Practices Bill 2011. Firstly, it describes force marriage as offence able and non-bailable act and cannot be used to settle disputes. Secondly, trading a female is not only a punishable and the accused person have to bear the imprisonment for 3 to 5 years but also have to pay find of RS 0.5 million. Thirdly, to deprive a female from her inheritance is also punishable and those people have to face between 5 to 10 years imprisonment or a fine of Rs 1 million and sometimes both. Finally, it elaborates the marriage of female with the Holy Quran is an offence and the person will have to pay fine of Rs 0.5 million and imprisonment from three to seven years.

However, the supporters of gender empowerment try to eradicate gender-based discrimination in strategy and agenda, initial evidence point out that several peace building and administrative frameworks and their implementation continuously unsuccessful to address the fundamental gender function and related authority dynamics that place the root for institutionalized gender discrimination.

Pakistani women are attentive in a web of dependence and subordination due to their low social, economic, and political status in society. The majority of women population suffers from all form of poverty. In order to change women's position and communities view of their weakness, fundamental modifications need to be brought about in the social and economic order that outline our social world. In Pakistan women are entirely missing from the state construction and administrative organizations that could initiate such structural changes. Women's addition in authoritative structure is necessary to bring about substantive changes in the development strategy and a program that would lead to a shift in gender relations in the society. Contemporary, in order to sustain the status quo, institutionalized violence against women at the house, society, and government levels are used as a mechanism to ensure their compliance with gender norms. This serves to prevent any attempt leading to the subversion of the male order.

Ironically, at the time, a great deal of metaphorical concentration has been paid to gender subject at the public level. Pakistan has also made numerous commitments at state and global forums to guarantee gender parity at home. Nevertheless, there is a broad gap between promise and execution. The persuasion of the state to translate its commitment to gender parity into tangible reality is the main confront faced by women in Pakistan. 
As population is an important power, the empowerment of the entire population will maximize Pakistan's power in the international community and hence enhance Pakistan internal security. The security will be enhanced because the rules will have eliminated any possible discord between the sexes at any future time through the provision of justice and the use of reasonable laws which are equally fair to both genders.

\section{Conclusion And Future Work}

In the light of the results of the present study, the research suggests that there are multiple ways to improve gender balance in the country which will enhance the non-traditional security and for reducing gender discrimination against females and providing them equal chances at the work place and in the society. First, the constitution of the Pakistan guarantees equal rights to all its citizens and so many laws guarantee equal chances of employment to both sexes; but neither government nor private organizations are acting upon those laws. Therefore a committee comprising of Judges, Representative of Ministry of Women Development, Media, NonGovernment Organizations (NGOs), Civil Society and Human Rights Commission of Pakistan (HRCP), should be constituted to inspect and investigate the matters of gender discrimination in work force.

Second, Government through media must start a mass awareness campaign on gender discrimination in employment. Especially the female employees must be informed about their rights and privileges. Third, NGOs should also come forward and highlight the cases of gender discrimination and help and support the victimized female employees in getting justice. Fourth, government should compel both public and private organizations to prepare annual reports regarding their human resource development. In that report they show how many male and female employees were appointed in the last year, what is the proportion of male and female employees in their total employment and government must appoint the females in each organization with the right proportion of their availability in the labor market and thus correct the past number mistake in employment.

Fifth, there is a need to invest more and more on female education because they are more than half of population in the country, and effort should be made by the government for entering more female in management and decision making posts in employment. Sixth, there is also need of implementation of laws in country through force and the government should take action as to who exploited the women rights, and the women harassment bill at the workplace and the women protection bill also needs to be implemented and this should not be seen as a mare piece of paper in the society. There is a need for proper legislation to prevent the growing incidents of violence against women in the country and urged to the parliamentarians to play their due role for curbing the menace from society. Last but not the least awareness must be created through media like the work of Sharmeen Obaid Chinoy "Saving Face" in which she highlighted one of the horrible accident of acid throwing at Pakistani female. In her acceptance speech, Chinoy dedicated the award to the women of Pakistan. She said "All the women in Pakistan working for change, don't give up on your dreams, this is for you". All these steps will ensure the women security in the Pakistan.

From the findings of this study, we have identified the following goal that we plan to follow in future. Validate these identified sectors using empirical studies with practitioners working on gender discrimination and its implications for Pakistan security.

\section{Limitations}

How valid are our findings of factors for gender discrimination in Pakistan security? One possible threat to internal validity is that for any specific article, their reported factors may not have in fact described underlying reason. We have not been able to independently control this threat. The authors of these studies were not supposed to report the original reasons why these factors were used during the gender discrimination from Pakistan's perspectives. It is also possible that in some studies there may have been a tendency for particular kinds of factors to be reported. Many of the contributing studies were self-reported experience reports, case studies and empirical studies which may be subject to publication bias.

How safe is it to generalise these findings? Our sample contains many articles from many countries. Our findings are not based on any studies that used a random sample of gender discrimination in Pakistan. However, in the investigation of our research questions, our study is the most comprehensive to date. The issue of generalising these findings can also be considered by comparing our findings with results from other related studies. We found many similarities in our findings and findings by other people, and this provides some support for generalisation.

\section{Acknowledgment}

We are thankful to faculty members of International Relations at Quaid-i-Azam University Islamabad Pakistan and the reviewer at University of Malakand Pakistan for validation of the paper. 


\section{Reference}

[1.] NTS can be define as challenges to the survival and well-being of peoples and states that arise primarily out of nonmilitary sources, such as climate change, cross-border environmental degradation and resource depletion, infectious diseases, natural disasters, irregular migration, food shortages, people smuggling, drug trafficking, and other forms of transnational crime. This definition of nontraditional security (NTS) has been adopted as the working definition by the Consortium of Non-Traditional Security Studies in Asia, otherwise known as NTS-Asia. For more details, see the NTS-Asia Web site at

[2.] www.rsis-nts.org, as well Pandey, Aditya ( edited ), "South Asia: Polity, Literacy and Conflict Resolution (Non-Traditional Security Approach; Institutional Perspective; Concept of the International Community; Implications for Regional Security)”, Delhi, 2005, Pp 27-59.

[3.] Hudson, Valerie M. , Caprioli, Mary , Ballif-Spanvill, Bonnie , McDermott, Rose , Emmett, Chad F. , "The Heart of the Matter: The Security of Women and the Security of States", Journal Article, International Security, volume 33, issue 3, Winter 2008/09 pages $7-45$

[4.] Spring, Úrsula Oswald, "Gender and Disasters Human, Gender and Environmental Security: A Huge Challenge", UNU Institute for Environment and Human Security (UNU-EHS), Germany March 2008, pp.25-26.

[5.] Ibid, p.26.

[6.] Alam, Anwar, "Impact of Gender Discrimination on Gender Development and Poverty Alleviation”, Sarhad J. Agric. Vol.27, No.2, 2011, p.330-331. As well http://www.tajzia.com/articles/2/1/Gender-Discrimination.html, retrieved on June 12,2012

[7.] Khtar, Qurratul Ain A, "Gender Discrimination", 27 April, 2007. http://www.tajzia.com/articles/2/1/Gender-Discrimination.html, retrieved on 21 December, 2011.

[8.] Dr. Farzana Bari, "16 Days", The News, 9 December 2010.

[9.] Hussain, Irshad, Adeeb, Muhammad Aslam, Safdar, Muhammad, Rahmanai, Sabiha Hameed, "Distance Education as a Strategy for Eliminating Gender Disparity in Pakistan” Iqraa (1998-2010). Islamabad

[10.] Tamana, Aazar, Inayat, Mavara, "Pakistan's National Security Domestic Dimension Women and Pakistan's Security", (ASSAS), Australia, 2011, p.91.

[11.] Perveen, Rakhshinda, "Gender-Based Violence in Pakistan: A scoping Study", Aurat Foundation, January, 2011.

[12.] Sethna, Razeshta, "The Forgotten Frontline", The Dawn, 20 September, 2011. Ibid.

[13.] Gul, Saba, Habib, Kiran, "Non Traditional and Human Security: Women and Human Security in South Asia Case Study of Pakistan", Institute of Regional Studies, NCHDI, Islamabad, P.294.

[14.] ${ }^{1}$ FF, Fikree, LI, Bhatti, "Domestic Violence and Health of Pakistani Women", The International Journal of Gynecology \& Obstetrics 1999; Vol 65, Pp195-201.

[15.] A, Bettencourt, "Violence against Women in Pakistan", Human Rights Advocacy Clinic; Litigation Report Spring 2000, www.du edu/intl/humanrights/violencepkstn.pdf, retrieved on 22 December, 2011

[16.] ${ }^{1}$ Human Rights Watch, 'Crime or Custom? Violence against Women in Pakistan, Report of Human Rights Watch 1999. http://www.hrw.org/reports/1999/pakistan/index.htm. Retrieved on 23 December, 2011

[17.] Human Rights Commission of Pakistan (HRCP), State of human rights in 1999. Lahore: HRCP, 2000.

[18.] Smith, Bradley F., J., M. Long, T., O. Dowd, Reported frequency of domestic violence: cross sectional survey of women attending general practice. British Medical Journal (BMJ) 2002; 324 (7332): 271.

[19.] Amnesty International, "Pakistan: Honour Killings of Girls and Women", September 1999. http://web.amnesty.org/library/Index/engASA330181999, retrieved on 13 December, 2011.Ibid

[20.] Patel, Rashida, "Women Versus Man Socio-Legal Gender Inequality in Pakistan", Murder for Male Honor, Oxford University Press, 18 December 2003, Pp.149-151.

[21.] Ibid, p.152.

[22.] Ibid, p.165.

[23.] Khel, Muhammad Ali baba, "Swara: Women as Property", Aurat Foundation, Peshawar, 2003, p.5.

[24.] Ibid, p.6

[25.] Raza, Talal, "Violence against Women", Retrieved from http://www.hamariweb.com/articles/article.aspx?id=6003, accessed on 12 December 2011.

[26.] Ibid.

[27.] Ibid.

[28.] Patel, Rashida, "Women Versus Man Socio-Legal Gender Inequality in Pakistan", Family Pressure, Oxford University Press Karachi 2011, p.48.

[29.] Asian Development Bank Report, 2000.

[30.] "National Education Policy of Pakistan", Ministry of Education, Government of Pakistan, Islamabad 2007.

[31.] Ministry of Women Development Islamabad Repot 2007.

[32.] Kazmi, Ghazala, "Gender Discrimination in Jobs Opportunities, and Impact on Gender Awareness in Public Sector organizations" Women Empowerment and Gender Rights and Planning Development Division/Commission Pakistan, April 2011.

[33.] Women and the Economy Organized by the World Bank, "Women and the Economy Summary of a Women Watch Online Discussion Moderated by the World Bank", November 23 - December 21, 2009.

[34.] Shahid, Ayesha, "Silent Voices, Untold Stories, Women Domestic Works in Pakistan and their Struggle for Empowerment", Oxford University Press, 2010, Pp. 124-125.

[35.] Ibid.

[36.] Haq, Mahbub ul, “A new framework for development cooperation”, United Nations Chronicle, 1993, Vol. 10, Issue 4, p.42.

[37.] K., Haq, 'Human Security for Women,' in Tehranian, M. (ed.), Worlds Apart: Human Security and Global Governance, London, I.B.Tauris Publishers, 1999, p. 96

[38.] Cheema, Pervaiz Iqbal, "Non Traditional and Human Security" Non Traditional and Human Security,

[39.] Institute of Regional Studies, NCHDI, Islamabad. P.353.

[40.] Ibid, p.10.

[41.] Weiner, Myron, Banuazizi, Ali (Eds), "The Politics of Social Transformation in Afghanistan, Iran and Pakistan", The Consequences of State Policies For Women in Pakistan, Syracuse University Press New York, P.312.

[42.] http://womenshistory.about.com/library/ency/blwh_pakistan_women.htm, retrieved on 19 December 2011.

[43.] Ibid, Weiner, p.13

[44.] Khan, Kashmali, "What Benazir did (not do) for women", The Express Tribune, June 30, 2010.

[45.] Benazir Bhutto - a symbol of empowered feminist 
[46.] http://app.com.pk/en /index.php?option=com content\&task=view\&id=170963\&Itemid=2, accessed on 23 December 2011.

[47.] http://www.dawn.com/01/16/nawaz-sharif.html2012/, accessed on 23 December 2011.

[48.] Naseer, Khawaja, "Women Politicians Snub Govt's Empowerment Efforts", Daily Times, 9 October 2002.

[49.] Najeeb, Muhammad, "More Women in Pakistan Polls Signals, Political Freedom", IANS Islamabad, 23 February 2008.

[50.] http://www.paktribune.com/news/print.php?id=162221, retrieved on 17 December 2011

[51.] Rahman, Javaid-ur-, "National Assembly Passes a Law against Women Harassment", The Nation, 22 January 2010

[52.] Khan, Zia, "National Assembly Passes Landmark Women's Rights Bill”, The Express Tribune, November 15, 2011.

[53.] Ibid

[54.] Manchanda, Rita (ed), "Women, War and Peace in South Asia: Beyond Victim hood to Agency", New Delhi: Sage Publications, 2001.

[55.] Asian Development Report 1998, p.7.

[56.] Channar, Zahid Ali, Panhawar, Panhawar, Iqbal A, "Gender Discrimination in Employment: A Comparative Study of Public \& Private Sectors of Pakistan", Australian Journal of Basic and Applied Sciences, Vol.4, No.11, 2010.

[57.] Director Sharmeen Obaid-Chinoy won the Best Documentary Short Subject for the film "Saving Face", at the 84th Academy Awards 26 February 2012

[58.] http://www.thenews.com.pk/article-37201-Sharmeen-Obaid-Chinoy-wins-Oscar,aswell http://tribune.com.pk/story/342358/sharmeen-obaid-chinoys-documentary-wins-oscar-for-best-documentary-short-subject/, retrieved on 27 March 2012 